\title{
Temporal changes in reproductive hormones and conceptus-endometrial interactions during embryonic diapause and reactivation of the blastocyst in European roe deer (Capreolus capreolus)
}

\author{
R. T. Lambert ${ }^{1}, 2 *$, C. J. Ashworth ${ }^{2 *}$, L. Beattie ${ }^{2}$, F. E. Gebbie ${ }^{3}$, \\ J. S. M. Hutchinson ${ }^{4}$, D. J. Kyle ${ }^{2}$ and P. A. Racey ${ }^{1}$ \\ ${ }^{1}$ Department of Zoology, University of Aberdeen, Aberdeen AB24 2TZ, UK; ${ }^{2}$ Rowett Research \\ Institute, Bucksburn, Aberdeen AB21 9SB, UK; ${ }^{3}$ Department of Applied Physiology, Scottish \\ Agricultural College, Craibstone Estate, Bucksburn, Aberdeen AB21 9YA, UK; ${ }^{4}$ Department of \\ Agriculture, University of Aberdeen, Aberdeen AB24 5UA, UK
}

The roe deer blastocyst is in diapause between August and December, after which time it expands and elongates rapidly before implantation. Blood samples were taken from 30 animals to define temporal changes in reproductively important hormones to investigate the physiological cues present at embryo reactivation. In 15 of these animals, changes in uterine and conceptus protein synthesis and secretion, and luteal progesterone release during diapause and reactivation, were assessed after culture of these tissues in vitro. Oestradiol concentrations remained low during diapause $\left(1.07 \pm 0.4 \mathrm{pg} \mathrm{ml}^{-1}\right)$ and expansion $(1.2 \pm 0.4 \mathrm{pg}$ $\mathrm{ml}^{-1}$ ) but increased by 30 times at trophoblast elongation $\left(49.17 \pm 0.37 \mathrm{pg} \mathrm{ml}^{-1}\right)$. Prolactin remained at basal concentrations $\left(4.69 \pm 0.86 \mathrm{ng} \mathrm{ml}^{-1}\right)$ and increased after implantation $\left(12.34 \pm 2.71 \mathrm{ng} \mathrm{ml}^{-1}\right)$. Peripheral progesterone concentrations and luteal progesterone release re- mained constant throughout diapause, reactivation and implantation (peripheral progesterone: $3.82 \pm 1.97 \mathrm{ng} \mathrm{ml}^{-1}$; luteal progesterone: $6.72 \pm 0.81 \mathrm{ng} \mathrm{mg}^{-1}$ protein). Incorporation of a radiolabel into conceptus secretory proteins increased by four times at expansion compared with diapause, whereas incorporation into endometrial secretions remained constant. At elongation, incorporation into endometrial secretions increased two times and conceptus secretions increased 32 times. Two-dimensional electrophoresis and fluorography showed that the profile of endometrial secretory proteins was constant until implantation when qualitative changes were evident. Although a role for an endocrine maternal trigger of reactivation from diapause cannot be dismissed, these data provide no supporting evidence and indicate that the conceptus itself may drive reactivation.

\section{Introduction}

Roe deer (Capreolus capreolus) undergo obligate embryonic diapause between early August and late December (Short and Hay, 1966; Aitken et al., 1973). The females have a single oestrus and mate during late July and early August (Short and Hay, 1966; Flint et al., 1994; Sempéré et al., 1998). The resulting blastocyst sheds its zona pellucida and enters a period of diapause at the 20-30-cell stage (Short and Hay, 1966; Aitken, 1974: Lange et al., 1998). The blastocyst undergoes a low level of mitosis during the last 6 weeks of diapause (Lengwinat and Meyer, 1996) and reactivates at approximately the 100-cell stage in early January (Renfree, 1982; Lange et al., 1998). After

*Present address: Department of Applied Physiology, Scottish Agricultural College, Craibstone Estate, Bucksburn, Aberdeen AB21 9YA, UK

Email: rogerlam@roedeer.org.uk elongation, the conceptus eventually forms a villous cotyledonary attachment to each of the uterine caruncular ridges (Aitken et al., 1973), the placental link is formed and fetal growth follows, with parturition taking place in late May and early June (Short and Hay, 1966; Aitken, 1974). Thus, the duration of gestation is approximately 10 months.

Evidence from other mammalian species with obligate embryonic diapause, such as mink (Mustela vison; Polejaeva et al., 1997) and western spotted skunk (Spilogale putorius latifrons; Kaplan et al., 1991), has shown a direct effect of temporal changes in concentrations of progesterone, oestradiol and prolactin on reactivation of diapausing blastocysts. However, the role of maternal hormones in reactivation of diapausing roe deer blastocysts has not been established (Short and Hay, 1966; Aitken et al., 1973; Aitken, 1974, 1979). Various factors could be associated with reactivation of roe deer blastocysts from diapause including an environmental cue, changes in the profile of maternal hormones or secretion of biochemical signals by 
the endometrium or conceptus. Alternatively, roe deer embryos may be programmed to reactivate at a particular age or developmental stage.

In natural conditions, reactivation from diapause coincides with the winter solstice. Young females exposed to a constant short photoperiod for 2 years showed a fertile oestrus in May with parturition occurring in late February and March, after a gestation period of 10 months (Sempéré et al., 1993, 1998). This experiment showed that the period of embryonic diapause was retained, indicating that diapause is the result of an endogenous rhythm.

During the 5 months between August and December the corpora lutea remain active regardless of whether the doe is pregnant. The corpora lutea regress in nonpregnant does coincident with blastocyst reactivation in pregnant does (Short and Hay, 1966; Hoffman et al., 1978; Aitken, 1979). Peripheral progesterone concentrations are constant throughout diapause and reactivation, and do not increase rapidly until after implantation (Sempéré, 1977; Hoffman et al., 1978). Similarly, total oestrogen concentrations in plasma do not increase until the time of trophoblast elongation. However, no study has adequately tested whether these hormones are responsible for reactivation. Aitken (1974) detected a $73.5 \mathrm{kDa}$ uterine-specific protein in the uterine luminal flushings of roe deer. This protein was more abundant during trophoblast elongation and implantation than during diapause, leading to the suggestion that this protein may be involved in embryo reactivation.

Roe deer are mono-oestrus (Short and Hay, 1966; Flint et al., 1994) and, therefore, do not require an embryonic signal to overcome luteolysis. Indeed, roe deer conceptuses do not secrete measurable quantities of either interferon-tau

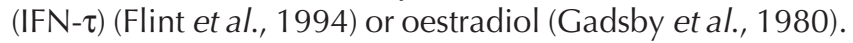
Nevertheless, an alternative embryonic signal may be involved in reactivation of diapausing roe deer blastocysts.

Few studies have been designed to test the ability of the conceptus to recommence development at the appropriate time. In the only study in which the relationship between embryo development and uterine function was perturbed experimentally, Broich et al. (1998) transferred a blastocyst, which had been cryopreserved for the preceding 6 weeks, into a mature doe in October. The experiment reduced the normal 5 month period of diapause by 6 weeks, with the birth of a single kid taking place at the normal time of late May.

The aim of the present study was to describe temporal changes in peripheral concentrations of key reproductive hormones, luteal activity and blastocyst-endometrial interactions during diapause, blastocyst expansion, trophoblast elongation and implantation. This information may provide greater understanding of the cues associated with reactivation of roe deer blastocysts from diapause.

\section{Materials and Methods}

\section{Animals}

Thirty roe does were culled, 28 of which were pregnant and two of which were not pregnant, on Glen Tanar,
Learney, Dunecht and Kincardine Estates, and by Forest Enterprise at Durris, in north east Scotland $\left(57^{\circ} .15^{\prime}\right.$ North, $2^{\circ} .52^{\prime}$ West), between 9 November and 28 January over 4 years (1995-1996, 1996-1997, 1997-1998, 1999-2000). The Forest Enterprise Head Ranger and the Head Keepers on the four estates estimated the ages of the deer as between 18 months and 4.5 years. Fifteen of the 28 pregnant animals, culled between 20 November and 28 January, were used to study endometrial-conceptus interactions in vitro. Blood samples were taken from all 30 animals for radioimmunoassay of reproductive hormones.

\section{Ethics of experimentation}

The cull animals were obtained during the period authorized under the Deer (Close Seasons) (Scotland) Order 1984 and were part of management culling practice. Additionally, five animals were culled from a captive population, again for management reasons. No animal was culled for the sole purpose of the study.

\section{Blood samples}

As soon as each roe deer was shot, the jugular vein was cut and blood was collected into sterile tubes, some of which contained heparin, which were placed immediately in ice. Blood samples were centrifuged within $1 \mathrm{~h}$ at $800 \mathrm{~g}$ at $4^{\circ} \mathrm{C}$ for $10 \mathrm{~min}$ and the plasma was aspirated and stored at $-20^{\circ} \mathrm{C}$. Tubes not containing heparin were stored at room temperature for $24 \mathrm{~h}$ to allow the serum to separate. The serum was then aspirated and stored at $-20^{\circ} \mathrm{C}$.

\section{Processing of reproductive tracts}

As soon as possible after death, the whole reproductive tract of each deer was removed under aseptic conditions and placed in a sterile thermos flask that had been warmed to body temperature of roe deer $\left(39^{\circ} \mathrm{C}\right)$. The reproductive tract was transported to the laboratory and the conceptuses were recovered under sterile conditions by irrigating the uterine lumen with sterile $0.9 \%(\mathrm{w} / \mathrm{v})$ saline solution. Individual conceptuses were measured under the microscope. The uterine flushing was centrifuged at $800 \boldsymbol{g}$ for $10 \mathrm{~min}$ at $4^{\circ} \mathrm{C}$ and stored at $-20^{\circ} \mathrm{C}$. The conceptuses and endometrial tissue were transferred to a laminar flow hood. Each individual conceptus was placed in a small Petri dish containing $3 \mathrm{ml}$ sterile minimum essential medium with Earle's salts with L-glutamine and without L-leucine (MEM; GibcoBRL, Life Technologies Ltd, Paisley) at $38.9^{\circ} \mathrm{C}$, supplemented with $5 \mathrm{ml}$ antibiotic-antimycotic solution (ABAM; Sigma Chemical Co., Poole) and $5.2 \mu \mathrm{g} \mathrm{ml}-1$ L-leucine (Sigma Chemical Co.). Finally, $50 \mu \mathrm{l} \mathrm{L-[4,5-}$ $\left.{ }^{3} \mathrm{H}\right]$ leucine (specific activity: $5.88 \mathrm{TBq} \mathrm{mmol}^{-1}$; Amersham Life Science, Little Chalfont) was added to radiolabel the proteins synthesized during culture. Approximately $300 \mathrm{mg}$ endometrial tissue was dissected from the uterus, cut into $1 \mathrm{~mm} \times 1 \mathrm{~mm}$ sections, placed in a Petri dish and weighed accurately under aseptic conditions. Supplemented MEM 
$(15 \mathrm{ml})$ at $38.9^{\circ} \mathrm{C}$ was added followed by $50 \mu \mathrm{l}\left[{ }^{3} \mathrm{H}\right]$ leucine. The endometrial tissue and conceptuses were cultured for $24 \mathrm{~h}$ at $38.9^{\circ} \mathrm{C}$ in a controlled atmosphere chamber on a rocking platform and gassed with a mixture of $45 \% \mathrm{O}_{2}: 50 \%$ $\mathrm{N}_{2}: 5 \% \mathrm{CO}_{2}$ for $10 \mathrm{~min}$ at $8 \mathrm{~h}$ intervals. After $24 \mathrm{~h}$ the culture medium from the endometrial tissue and the conceptuses was aspirated and stored at $-20^{\circ} \mathrm{C}$.

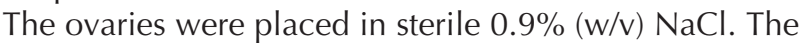
corpora lutea were dissected from the ovaries, weighed and minced. Individual minced corpora lutea were cultured in TCM-199 (GibcoBRL) supplemented with ABAM in a ratio of $500: 1$ at $38^{\circ} \mathrm{C}$ for $2 \mathrm{~h}$. After centrifugation at $800 \mathrm{~g}$ for 10 min at $4^{\circ} \mathrm{C}$, the medium was aspirated and stored at $-20^{\circ} \mathrm{C}$ before progesterone assay. The minced luteal tissue was stored at $-20^{\circ} \mathrm{C}$ for subsequent estimation of protein content.

\section{Dialysis of conceptus, endometrial and uterine flushing proteins}

Uterine flushings and endometrial and conceptus culture media samples were dialysed in individual molecular porous membrane tubes (Spectra/Porr Molecularporous Membrane Tubing; Medicell International Ltd, London), with a 3500 molecular weight cut-off, against three changes of $10 \mathrm{mmol}$ Tris $-\mathrm{HCl} \mathrm{I} \mathrm{I}^{-1}$ at $\mathrm{pH} 8.2$ at $4^{\circ} \mathrm{C}$. The uterine flushings were frozen at $-20^{\circ} \mathrm{C}$ before estimation of protein content. Aliquots of dialysed culture media samples were precipitated with trichloroacetic acid (Mans and Novelli, 1961) to determine de novo synthesis and secretion.

\section{Estimation of total protein content of uterine flushings}

Total protein content of the dialysed uterine luminal flushing of each animal was measured according to the method of Bradford (1976) using BSA as a standard. Volumes of uterine flushings containing $500 \mu \mathrm{g}$ protein were freeze-dried.

\section{Estimation of total protein content of corpora lutea}

Luteal tissue samples were solubilized by overnight incubation with $2 \mathrm{ml}$ of $2 \%(\mathrm{w} / \mathrm{v})$ sodium hydroxide at $39^{\circ} \mathrm{C}$ on a rocking platform. Luteal protein content was determined in each individual minced corpus luteum tissue sample using the method of Bradford (1976). Luteal progesterone release was expressed as $\mathrm{ng} \mathrm{mg}^{-1}$ protein.

\section{Isoelectric focusing and two-dimensional electrophoresis}

Conceptus culture medium from animal reference numbers 1-5 (Table 1) was pooled. This pooled sample contained 90442 d.p.m. This sample and samples of radiolabelled endometrial proteins containing 400000 d.p.m. were separated by two-dimensional PAGE using $10 \%(\mathrm{w} / \mathrm{v})$ acrylamide in the second dimension and were visualized by fluorography as described by Roberts et al. (1984). Samples of uterine luminal flushings containing $500 \mu \mathrm{g}$ protein were also separated by two-dimensional PAGE using 10\% (w/v) acrylamide gels.

\section{Radioimmunoassay of blood samples, uterine flushings and luteal secretions}

Progesterone concentrations were determined for roe deer serum and plasma samples using a [ $\left.{ }^{125} \mathrm{I}\right]$-labelled progesterone double antibody radioimmunoassay (McNeilly and Fraser, 1987). The assays were modified for use with

Table 1. Conceptus, corpora lutea and endometrial samples collected from pregnant roe deer

\begin{tabular}{|c|c|c|c|c|c|}
\hline $\begin{array}{l}\text { Doe } \\
\text { reference } \\
\text { number }\end{array}$ & $\begin{array}{c}\text { Stage of } \\
\text { pregnancy }\end{array}$ & $\begin{array}{c}\text { Number of } \\
\text { corpora lutea }\end{array}$ & $\begin{array}{c}\text { Number of } \\
\text { conceptuses }\end{array}$ & Size of conceptuses & $\begin{array}{c}\text { Date of } \\
\text { collection }\end{array}$ \\
\hline 1 & Blastocyst at diapause & 2 & 2 & $0.29 \mathrm{~mm} \times 0.27 \mathrm{~mm}$ and $0.26 \mathrm{~mm} \times 0.25 \mathrm{~mm}$ & 22 November 1995 \\
\hline 2 & Blastocyst at diapause & 2 & 1 & $0.29 \mathrm{~mm} \times 0.17 \mathrm{~mm}$ & 28 November 1995 \\
\hline 3 & Blastocyst at diapause & 2 & 2 & $0.37 \mathrm{~mm} \times 0.35 \mathrm{~mm}$ and $0.28 \mathrm{~mm} \times 0.18 \mathrm{~mm}$ & 20 December 1995 \\
\hline 4 & Expanding blastocyst & 2 & 2 & $0.70 \mathrm{~mm} \times 0.60 \mathrm{~mm}$ and $0.65 \mathrm{~mm} \times 0.45 \mathrm{~mm}$ & 2 January 1997 \\
\hline 5 & Expanding blastocyst & 2 & 1 & $1.50 \mathrm{~mm} \times 1.05 \mathrm{~mm}$ & 5 January 1998 \\
\hline 6 & Elongated trophoblast & 2 & 1 & Length of trophoblast $90 \mathrm{~mm}$ & 23 January 1998 \\
\hline 7 & Elongated trophoblast & 2 & 1 & Inner cell mass $5 \mathrm{~mm} \times 4 \mathrm{~mm}$ & 6 January $2000^{a}$ \\
\hline 8 & Implanted fetus & 2 & 2 & $\mathrm{C}-\mathrm{R}: 7 \mathrm{~mm}$ and $5 \mathrm{~mm}$ & 27 January 1998 \\
\hline 9 & Implanted fetus & 2 & 2 & $\mathrm{C}-\mathrm{R}: 7.5 \mathrm{~mm}$ and $7 \mathrm{~mm}$ & 28 January 1998 \\
\hline 10 & Implanted fetus & 3 & 1 & $\mathrm{C}-\mathrm{R}: 8 \mathrm{~mm}$ & 6 January $2000^{a}$ \\
\hline 11 & Implanted fetus & 2 & 2 & C-R: $12 \mathrm{~mm}$ and $9 \mathrm{~mm}$ & 24 January 1997 \\
\hline 12 & Implanted fetus & 2 & 2 & C-R: $17 \mathrm{~mm}$ and $14 \mathrm{~mm}$ & 12 January $2000^{a}$ \\
\hline 13 & Implanted fetus & 3 & 2 & C-R: $18 \mathrm{~mm}$ and $17 \mathrm{~mm}$ & 6 January $2000^{a}$ \\
\hline 14 & Implanted fetus & 3 & 3 & C-R: $18 \mathrm{~mm}, 17 \mathrm{~mm}$ and $16 \mathrm{~mm}$ & 12 January $2000^{a}$ \\
\hline 15 & Implanted fetus & $1^{b}$ & 2 & C-R: $22 \mathrm{~mm}$ and $20 \mathrm{~mm}$ & 6 January $2000^{a}$ \\
\hline
\end{tabular}

C-R: crown-rump length

aDeer from captive population (all other animals culled in 'wild').

${ }^{b}$ Only one ovary recovered. 
rabbit anti-progesterone, donkey anti-rabbit $\operatorname{IgG}$ and normal rabbit sera, which were obtained as gifts from the Scottish Antibody Production Unit (Carluke, Scotland). Progesterone was extracted from the serum or plasma with $77 \%$ efficiency using diethyl ether. The sensitivity of the assay was $0.73 \mathrm{ng} \mathrm{ml}^{-1}$. The serum and plasma samples were run in a single assay and the intra-assay coefficients of variation for quality control of low $\left(1.07 \mathrm{ng} \mathrm{m}^{-1}\right)$, medium $\left(2.56 \mathrm{ng} \mathrm{ml}^{-1}\right)$ and high $\left(6.04 \mathrm{ng} \mathrm{ml}^{-1}\right)$ concentrations were $7.8,5.0$ and $4.9 \%$, respectively. Luteal progesterone concentrations were determined without prior extraction using the assay outlined above. Culture medium (TCM-199) was added to the standard curves and used to dilute luteal culture medium samples as required. The sensitivity of the assays was $0.60 \mathrm{ng} \mathrm{ml}^{-1}$. The intra- and interassay coefficients of variation for quality control of low (1.34 ng $\mathrm{ml}^{-1}$ ), medium (2.22 $\left.\mathrm{ng} \mathrm{ml}^{-1}\right)$ and high (4.14 $\mathrm{ng} \mathrm{ml}^{-1}$ ) concentrations were $16.5,6.4$ and $5.8 \%$ (intra-assay) and $21.7,6.3$ and $5.8 \%$ (interassay), respectively.

Plasma and serum oestradiol concentrations were measured using a [125I]-labelled extraction oestradiol radioimmunoassay (Mann et al., 1995). The sensitivity of the assay was $0.394 \mathrm{pg} \mathrm{ml}^{-1}$. Extraction efficiency was $80 \%$. The samples were analysed in two assays and the intra- and interassay coefficients of variation for quality control of low (1.49 $\left.\mathrm{pg} \mathrm{ml}^{-1}\right)$, medium $\left(3.02 \mathrm{pg} \mathrm{ml}^{-1}\right)$ and high (5.01 $\left.\mathrm{pg} \mathrm{ml}^{-1}\right)$ concentrations were 11.6, 5.3 and $7.5 \%$ (intra-assay) and $11.6,7.2$ and $8.3 \%$ (interassay), respectively.

Plasma and serum prolactin samples were available from 22 pregnant animals and were measured, together with samples of uterine flushing and luteal culture medium, using a modified double antibody radioimmunoassay method (Hart, 1973; Gala and Hart, 1980). The guinea-pig anti-ovine prolactin was obtained as a gift from I. A. Forsyth (Babraham Institute, Cambridge). The rabbit anti-guinea pig IgG was obtained from Biogenesis (Poole). The normal guinea-pig serum was obtained as a gift from the Scottish Antibody Production Unit (Carluke). The sensitivity of the assay was $3.0 \mathrm{ng} \mathrm{ml}^{-1}$. Intra- and interassay coefficients of variation for quality control of low $\left(5.02 \mathrm{ng} \mathrm{ml}^{-1}\right)$, medium (14.31 ng ml-1) and high (31.51 $\mathrm{ng} \mathrm{ml}^{-1}$ ) concentrations were $11.9,12.8$ and $15.1 \%$ (intra-assay) and $11.8,12.2$ and $15.1 \%$ (interassay), respectively.

\section{Pregnancy-associated glycoproteins}

Serum pregnancy-associated glycoprotein concentrations were measured in 22 samples from pregnant roe deer using a double-antibody radioimmunoassay modified for ovine samples (Zoli et al., 1992). The standard, first antibody and second antibody were obtained as gifts from J-F. Beckers and J. Sulon (Faculty of Veterinary Medicine, University of Liège, Liège). The sensitivity of the assay was $4.5 \mathrm{ng} \mathrm{ml}^{-1}$. Intra-assay coefficients of variation for quality control of low $\left(10.91 \mathrm{ng} \mathrm{ml}^{-1}\right)$, medium $\left(20.47 \mathrm{ng} \mathrm{ml}^{-1}\right)$ and high (43.22 $\mathrm{ng} \mathrm{ml}^{-1}$ ) concentrations were $8.8,4.8$ and $3.9 \%$, respectively.

\section{Statistical analyses}

Data from all animals were expressed relative to conceptus development regardless of the date and year in which the samples were collected (Table 1 ). Incorporation data were separated into: (i) blastocyst in diapause $(n=3)$; (ii) expansion of the blastocyst $(n=2)$; (iii) elongated trophoblast stage of conceptus development $(n=2)$; and (iv) implantation and subsequent fetal growth $(n=8)$. Incorporation of the radiolabel in both conceptus and endometrial protein synthesis de novo is expressed relative to the mean diapause value for each of the defined developmental stages. Doe means were calculated for animals with two or more conceptuses or corpora lutea. Values are expressed as mean \pm SEM. The significance of differences between the developmental stages of diapause and expansion was determined using Student's $t$ test. $P<0.05$ was considered significant.

Peripheral hormone concentration values for serum and plasma progesterone, oestradiol, prolactin and luteal progesterone release (mean \pm SEM) were calculated for the periods of: (i) diapause; (ii) blastocyst expansion; (iii) elongation of trophoblast; and (iv) implantation. The number of estimations for each hormone at each developmental stage is shown (Table 2). ANOVA was used to determine whether the stage of conceptus development affected peripheral hormone concentrations.

\section{Results}

\section{Number of conceptuses and corpora lutea recovered}

Fifteen pregnant does were used to study conceptusendometrial interactions in vitro. The samples are shown in relation to the developmental stage of the conceptus (Table 1 ). The total numbers of corpora lutea and conceptuses in the pregnant does were 32 and 26, respectively. Conceptus development ranged from a blastocyst $0.26 \mathrm{~mm}$ in diameter at diapause to an implanted fetus of $22 \mathrm{~mm}$ crown-rump length.

\section{Incorporation of radiolabel into endometrial secretory proteins}

Incorporation of the radiolabel into endometrial secretions was similar during diapause and blastocyst expansion (5202 \pm 88.5 d.p.m. $\mathrm{mg}^{-1} ; n=5$; Fig. 1 ). At the elongated trophoblast stage, incorporation into endometrial secretory proteins had increased two times compared with the diapause and expansion stages (Fig. 1). After implantation, endometrial secretions decreased as fetal size increased $($ slope $=-0.00108$, intercept $=20.9)($ Fig. 2) .

\section{Incorporation of radiolabel into conceptus secretory proteins}

During diapause, incorporation of radiolabel into conceptus secretory proteins was $2620 \pm 927$ d.p.m. per conceptus. At the initial stages of blastocyst expansion (doe reference numbers 4 and 5; Table 1), incorporation 
Table 2. Concentrations of maternal hormones in pregnant roe deer

\begin{tabular}{|c|c|c|c|c|c|}
\hline \multirow[b]{2}{*}{ Hormone } & \multicolumn{4}{|c|}{ Stage of development } & \multirow[b]{2}{*}{$P$ value } \\
\hline & Diapause & Expansion & Elongation & Implantation & \\
\hline $\begin{array}{l}\text { Serum/plasma } \\
\text { progesterone }\left(\mathrm{ng} \mathrm{ml}^{-1}\right)\end{array}$ & $4.03 \pm 1.09(n=15)$ & $3.15 \pm 0.68(n=3)$ & $2.46 \pm 0.96(n=2)$ & $3.67 \pm 1.6(n=8)$ & ns \\
\hline $\begin{array}{l}\text { Luteal progesterone } \\
\text { (ng mg } \text { m }^{-1} \text { protein) }\end{array}$ & $7.03 \pm 0.8(n=3)$ & $6.9 \pm 0.8(n=2)$ & $7.09 \pm 0.12(n=2)$ & $6.47 \pm 0.94(n=8)$ & ns \\
\hline $\begin{array}{l}\text { Serum/plasma } \\
\text { oestradiol }\left(\mathrm{pg} \mathrm{ml}^{-1}\right)\end{array}$ & $1.07 \pm 0.4(n=15)$ & $1.2 \pm 0.4(n=3)$ & $49.17 \pm 0.37(n=2)$ & $12.8 \pm 13.7(n=8)$ & $P<0.01$ \\
\hline $\begin{array}{l}\text { Serum/plasma } \\
\text { prolactin }\left(\mathrm{ng} \mathrm{m}^{-1}\right)\end{array}$ & $4.66 \pm 0.72(n=15)$ & $5.47 \pm 1.26(n=3)$ & $3.91(n=1)$ & $12.34 \pm 2.71(n=3)$ & ns \\
\hline
\end{tabular}

aANOVA between the four developmental stages. ns: not significant.

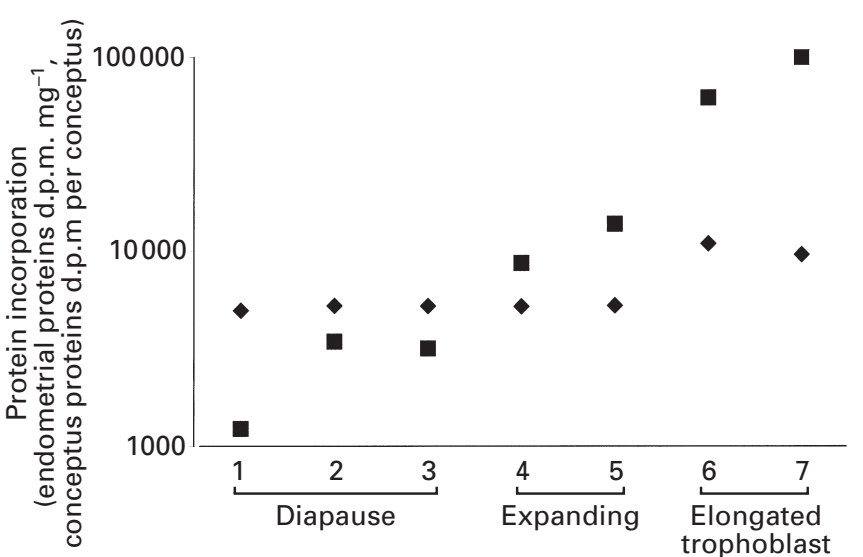

Fig. 1. Incorporation of radiolabel into newly synthesized conceptus $(\boldsymbol{\square})$ and endometrial $(\bullet)$ proteins in relation to conceptus development in roe deer. Doe reference numbers 1-7 (Table 1).

had increased to an overall mean value of $11250 \pm 2550$ d.p.m. per conceptus $(n=3)$, which represents a 4.3 times increase from diapause $(P<0.05 ;$ Fig. 1$)$. At the elongated trophoblast stage, incorporation was $85822 \pm 24032$ d.p.m. per conceptus $(n=2)$, which is an increase of 32.7 times compared with diapause values (Fig. 1).

\section{Two-dimensional electrophoresis}

Endometrium. The profile of endometrial secretory proteins showed some increase in incorporation of radiolabel between diapause (Fig. 3a), expansion (Fig. 3b) and elongated trophoblast (Fig. 3c) stages, but the most pronounced qualitative differences were evident after implantation (Fig. 3d). Most of the radiolabelled endometrial proteins secreted during diapause, expansion and at the elongated trophoblast stage had isoelectric points (pl) between 5.4 and 6.6. Secretion of proteins with a molecular mass of approximately 55-60 kDa and a pl value between 6.6 and 7.9 increased during the period of rapid embryonic

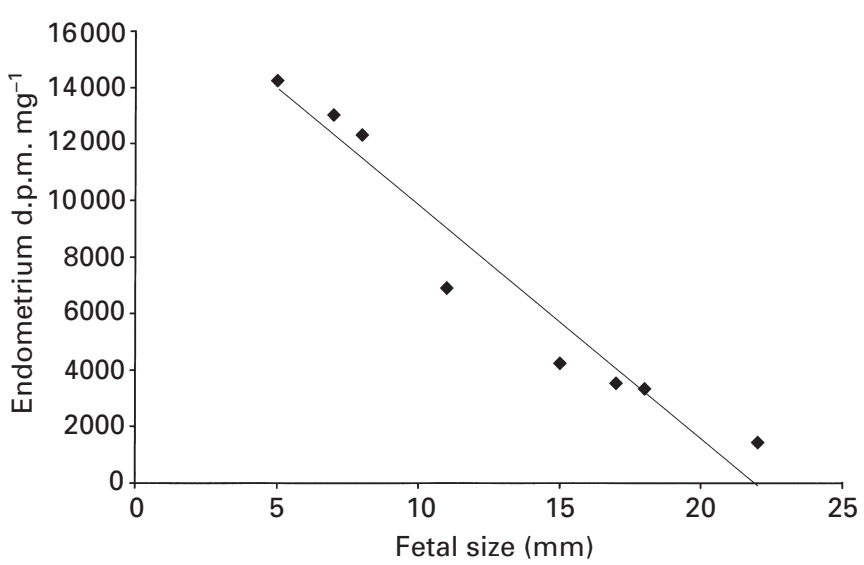

Fig. 2. Relationship between de novo endometrial protein synthesis in vitro and fetal crown-rump length (fetal size) in roe deer. Slope $=-0.00108$ and intercept $=20.9(P \leqslant 0.05)$.

growth before implantation. After implantation, there was a significant shift towards these basic proteins.

Conceptus. The dominant radiolabelled conceptus secretory protein had a molecular mass of $66000 \mathrm{Da}$ and pl 6.2 (Fig. 4).

\section{Uterine flushings}

Visual examination of the two-dimensional gels produced from uterine luminal flushings showed a consistent profile during diapause (Fig. 5). This profile was similar during blastocyst expansion and at the elongated trophoblast stage.

\section{Peripheral progesterone concentrations and luteal progesterone release}

Data describing peripheral progesterone concentrations were available for 28 pregnant does, including the 15 pregnant does used for in vitro culture of endometrial and 


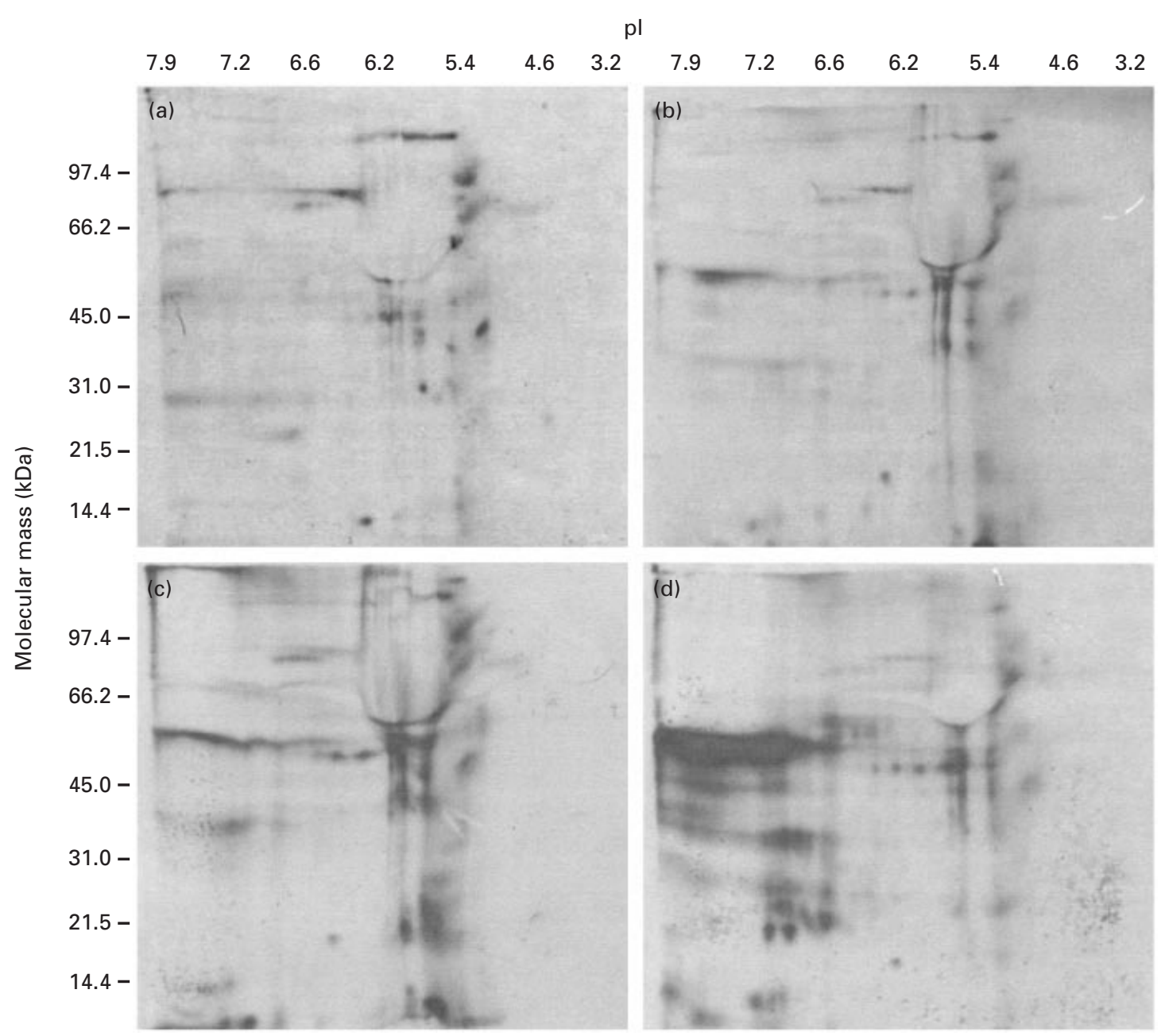

Fig. 3. Representative fluorographs showing newly synthesized endometrial proteins secreted during (a) diapause, (b) expansion, (c) elongation and (d) implantation in roe deer. Most of the proteins secreted during diapause and elongation had isoelectric points (pl) between 5.4 and 6.6. Secretion of proteins with a molecular mass of approximately 55-60 kDa and a pl value between 7.9 and 6.6 increased during elongation (b and c) before implantation. After implantation (d) these basic proteins were predominant.

conceptus tissues. Peripheral progesterone concentrations remained constant throughout diapause, blastocyst expansion, elongated trophoblast stage and implantation (mean $3.82 \pm 1.97 \mathrm{ng} \mathrm{ml}^{-1}$ ) (Table 2). Luteal progesterone release from the 15 animals used for in vitro culture also remained constant during diapause, expansion, elongated trophoblast stage and implantation (mean $6.72 \pm 0.81 \mathrm{ng}$ $\mathrm{mg}^{-1}$ protein) (Table 2).

Data were also available from two nonpregnant does with active corpora lutea. The peripheral progesterone concentrations were 3.25 and $3.68 \mathrm{ng} \mathrm{ml}^{-1}$, and luteal progesterone release was 7.66 and $7.70 \mathrm{ng} \mathrm{mg}^{-1}$ protein.

\section{Oestradiol}

Data describing peripheral oestradiol concentrations were available for 28 pregnant does (Table 2). Concentrations were consistently low throughout diapause $(1.07 \pm 0.4 \mathrm{pg}$ $\left.\mathrm{ml}^{-1}\right)$ and expansion $\left(1.2 \pm 0.4 \mathrm{pg} \mathrm{m}^{-1}\right)$ but increased 30 times at the elongated trophoblast stage $(49.17 \pm 0.37 \mathrm{pg}$ $\mathrm{ml}^{-1}$ ). Concentrations remained high after implantation $\left(12.8 \pm 3.7 \mathrm{pg} \mathrm{ml}^{-1}\right)$.

\section{Prolactin}

Peripheral prolactin values were available for 22 animals (Table 2). Prolactin concentrations remained constant during diapause, expansion and elongation (mean $4.69 \pm$ $0.86 \mathrm{ng} \mathrm{ml}^{-1}$ ). After implantation, prolactin concentrations increased by 2.6 times. Prolactin concentrations in the uterine luminal flushings and luteal secretions were below detectable concentrations $\left(<3.0 \mathrm{ng} \mathrm{ml}^{-1}\right)$.

\section{Pregnancy-associated glycoproteins}

Data describing concentrations of pregnancy-associated glycoproteins in roe deer serum were available for 22 


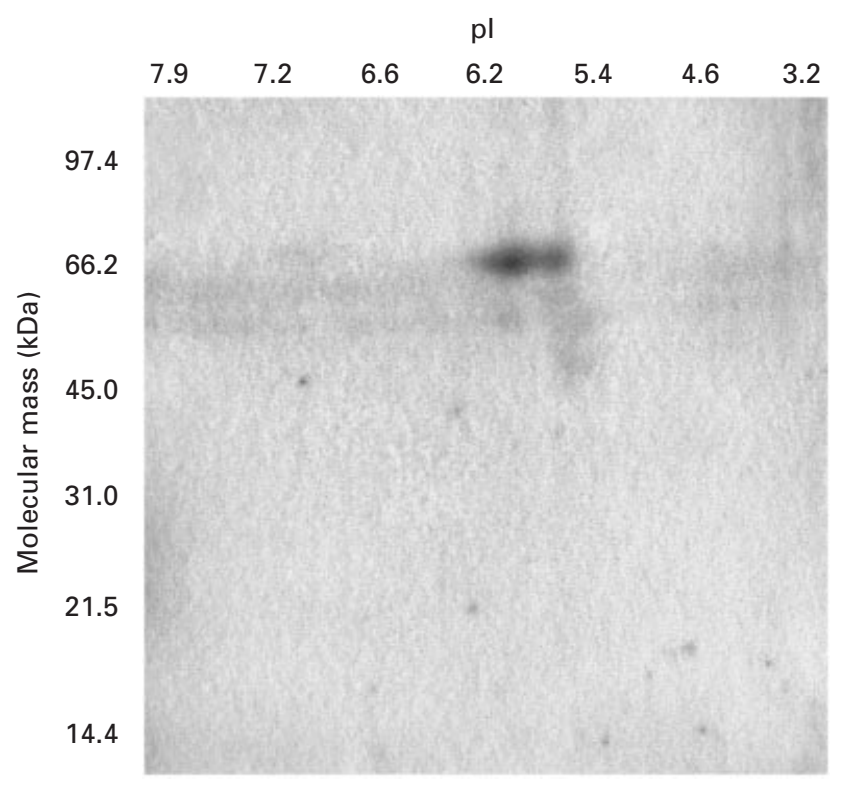

Fig. 4. Fluorograph of radiolabelled protein secretions from pooled roe deer conceptus culture media. The dominant secretory protein had a molecular mass of $66000 \mathrm{Da}$ and pl value of 6.2 .

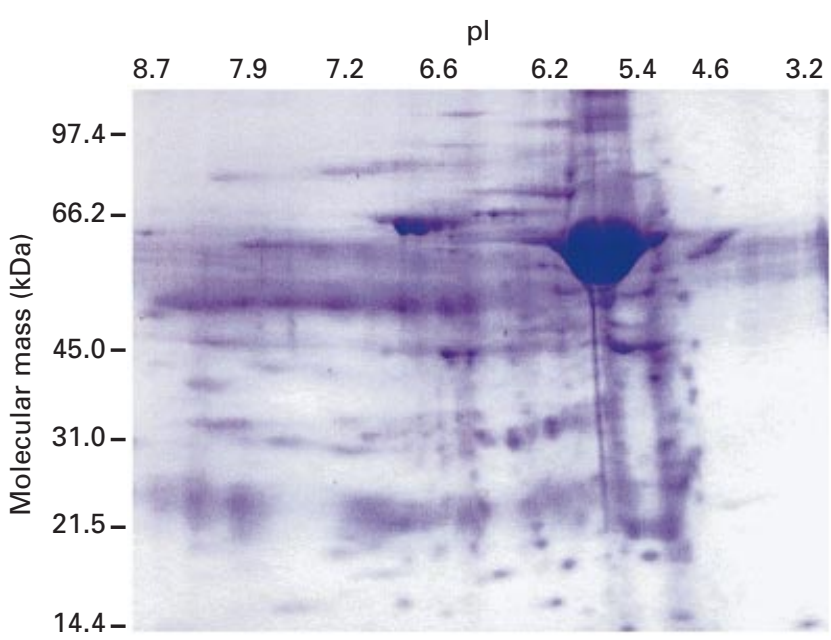

Fig. 5. Representative two-dimensional electrophoresis gel showing protein composition of uterine flushings from pregnant roe deer. The profile of the uterine flushings remained consistent during diapause and the period of rapid embryonic growth before implantation.

pregnant animals. Pregnancy-associated glycoproteins were below detectable concentrations $\left(<4.5 \mathrm{ng} \mathrm{ml}^{-1} ; n=19\right)$ throughout diapause, expansion and elongation, until after implantation when they increased to a mean of $7.74 \pm 0.475$ $n g \mathrm{ml}^{-1}(n=3)$.

\section{Discussion}

This study describes temporal changes in conceptus and uterine biochemistry after in vitro culture of roe deer embryos and endometrial tissue. The observations, from a limited number of samples, show that a significant increase in conceptus protein secretion precedes a more modest increase in endometrial protein secretion.

Nonpregnant does maintain active corpora lutea for the 5 months corresponding to the period of diapause in pregnant does. No significant differences in luteal progesterone release and peripheral progesterone concentrations were observed during this period between pregnant and nonpregnant does in the present study or in the study of Hoffman et al. (1978). It is clear that the blastocyst plays no role in the maintenance of luteal function (Flint, 1995), as does maintain, via the corpora lutea, an optimal uterine environment whether or not they are pregnant. Neither the study of Lengwinat and Meyer (1996) nor the results of the present study indicate any change in the uterine environment during diapause or specifically during blastocyst mitosis, which occurs during the last 2 months of diapause (Lengwinat and Meyer 1996), indicating that the blastocyst controls its own growth.

Data from the present study show no significant changes in peripheral progesterone concentrations or luteal progesterone release during diapause, blastocyst expansion, trophoblast elongation and implantation. Sempéré (1977) and Hoffman et al. (1978) described an increase in peripheral progesterone concentrations after implantation. Data from the present study show that neither peripheral nor luteal progesterone concentrations increased during early fetal development. Therefore, it is unclear whether the reported increase (Sempéré, 1977; Hoffman et al., 1978) in peripheral progesterone concentrations is placental or luteal in origin. Data from the present study show that such an increase is a consequence of implantation rather than a cause. In the present study, peripheral oestradiol concentrations were consistently low during diapause and blastocyst expansion, but increased markedly at the elongated trophoblast stage, although it is not clear whether the source of this hormone is ovarian or adrenal. Prolactin remained at basal concentrations until implantation, indicating that it probably does not play a role in either blastocyst reactivation or rapid embryonic growth.

Endocrine data from the present study and reported previously (Short et al., 1966; Sempéré, 1977; Hoffman et al., 1978) indicate that progesterone, oestradiol and prolactin do not provide a maternal hormonal trigger for reactivation of the blastocyst from diapause in roe deer. However, without sampling these hormones on a daily basis during the crucial period of December and January, it is possible that a transient endocrine signal could be missed.

Aitken (1974) detected a 67-80 kDa uterine-specific protein in roe uterine luminal flushings at the time of embryonic elongation and, to a lesser extent, during 
diapause. The present study extends these initial findings. Acidic proteins of similar molecular masses to those described by Aitken (1974) are synthesized and secreted by roe deer endometrium. Furthermore, these data indicate that secretion of these proteins may increase as the blastocyst develops from diapause to an elongated trophoblast.

Broich et al. (1998) experimentally perturbed the relationship between embryo development and uterine function; a blastocyst, which had been cryopreserved for the preceding 6 weeks, was transferred into a mature doe in October. The result was a reduction in the period of diapause by 6 weeks, with birth of a single kid occurring at the normal time of late May. The results of this experiment (Broich et al., 1998) support the hypothesis that a maternal signal controls blastocyst reactivation but, as demonstrated by Lengwinat and Meyer (1996), blastocyst mitosis takes place in the latter period of diapause only so it is possible that the reintroduced blastocysts were at the same developmental stage as the blastocysts in utero.

The question remains as to what triggers roe deer conceptuses to reactivate in the apparent absence of any of the maternal hormonal cues associated with reactivation in other species with embryonic diapause. Although our data are limited for the period of reactivation, the increased secretory activity of the blastocyst at this stage of development, which commences before increased secretory activity of the endometrium, may indicate that these blastocyst secretions initiate reactivation. As pregnancyassociated glycoproteins were found in roe deer serum after implantation and the dominant blastocyst secretory protein is of similar size and $\mathrm{pl}$ value to pregnancy-associated glycoproteins (Xie et al., 1994; Roberts et al., 1996) it is possible that the secreted blastocyst protein is a pregnancyassociated glycoprotein specific to roe deer. Although the role of pregnancy-associated glycoproteins remains unclear (Roberts et al., 1996), increased protein secretion by the blastocyst could provide the trigger for the onset of a maternal response from the endometrium. These preliminary findings need to be investigated further with a larger sample and the presence of pregnancy-associated glycoproteins in the conceptus secretory proteins should be confirmed or otherwise. However, in the light of the present data, it seems possible that the embryo is genetically programmed to recommence development at a given developmental stage or age, although the possibility of a presently unknown maternal physiological trigger cannot be discounted.

In conclusion, the results of the present study show that luteal progesterone release, and peripheral progesterone, oestradiol and prolactin concentrations are consistently low during diapause and blastocyst reactivation. This finding indicates that conceptus reactivation is probably not a response to any of the more likely maternal endocrine triggers and that the conceptus acts autonomously. This hypothesis warrants further investigation.

The research was supported by the British Deer Society and the University of Aberdeen. The authors sincerely thank M. Ewen,
S. Robertson, K. Mackie and A. Thain (SAC, Aberdeen) for their technical help and G. Horgan (BioSS) for statistical advice. The authors would also like to thank A. Bradford for permission to cull animals on Kincardine Estate, Aboyne, Aberdeenshire, E. Smith, Head Keeper at Glen Tanar Estate, W. Taylor, Forest Enterprise, Durris, I. Feaks, Head Keeper at Dunecht Estates and A. Sørenson of Scotsport, Ballater, for providing the other culled animals.

\section{References}

Aitken RJ (1974) Delayed implantation in roe deer (Capreolus capreolus) Journal of Reproduction and Fertility $39225-233$

Aitken RJ (1979) The hormonal control of implantation. In Maternal Recognition of Pregnancy pp 53-81. Ciba Foundation Symposium 64, Excerpta Medica, Amsterdam

Aitken RJ, Burton J, Hawkins J, Kerr-Wilson R, Short RV and Steven DH (1973) Histological and ultrastructural changes in the blastocyst and reproductive tract of the roe deer (Capreolus capreolus) during delayed implantation Journal of Reproduction and Fertility 34 481-493

Bradford MM (1976) A rapid and sensitive method for the quantitation of microgram quantities of protein, utilising the principle of protein dye binding Analytical Biochemistry 72 248-254

Broich A, Goeritz F, Lange A, Gilles M, Hermes R, Lengwinat T, Jewgenow K, Baugatz C and Hildebrandt T (1998) Superovulation and embryo transfer in European roe deer (Capreolus capreolus). In Advances in Deer Biology, Proceedings of the $4^{\text {th }}$ International Biology of Deer Congress pp 160-163 Ed. Z Zomborsky. Pannon University of Agriculture, Kaposvár

Flint APF (1995) Interferon, the oxytocin receptor and the maternal recognition of pregnancy in ruminants and non-ruminants: a comparative approach Reproduction Fertility and Development 7 $313-318$

Flint APF, Krzywinski A, Sempéré AJ, Mauget R and Lacroix A (1994) Luteal oxytocin and monoestry in the roe deer (Capreolus capreolus) Journal of Reproduction and Fertility 101 651-656

Gadsby JE, Heap RB and Burton RD (1980) Oestrogen production by blastocyst and early embryonic tissue of various species Journal of Reproduction and Fertility $60409-417$

Gala RR and Hart IC (1980) Serum prolactin heterogeneity in the cow and goat Life Sciences 27 723-730

Hart IC (1973) Basal levels of prolactin in goat blood measured throughout a $24 \mathrm{~h}$ period by double antibody-solid phase radioimmunoassay Journal of Dairy Research 40 235-245

Hoffman B, Barth D and Karg H (1978) Progesterone and oestrogen levels in peripheral plasma of the pregnant and non pregnant roe deer Biology of Reproduction 19 931-935

Kaplan JB, Berria M and Mead RA (1991) Prolactin levels in the western spotted skunk: changes during pre- and peri-implantation and effects of melatonin and lesions to the anterior hypothalamus Biology of Reproduction 44 991-997

Lange A, Broich A, Gilles M, Hermes R, Glatzel P, Hildebrandt T and Goëritz F (1998) New approaches to embryonic development in European roe deer (Capreolus capreolus) using embryo transfer Journal of Reproduction and Fertility Abstract Series 2233 (Abstract)

Lengwinat T and Meyer HHD (1996) Investigations of BrdU incorporation in roe deer blastocysts in vitro. Animal Reproduction Science $\mathbf{4 5}$ 103-107

McNeilly AS and Fraser HM (1987) Effect of gonadotrophin-releasing hormone agonist-induced suppression of $\mathrm{LH}$ and FSH on follicle growth and corpus luteum function in the ewe Journal of Endocrinology 115 273-282

Mann GE, Lamming GE and Fray MD (1995) Plasma oestradiol and progesterone during early pregnancy in the cow and the effects of treatment with buserelin Animal Reproduction Science 37 121-131

Mans RJ and Novelli GD (1961) Measurement of the incorporation of radioactive amino acids into protein by a filter-paper disk method Archives of Biochemistry and Biophysics 94 48-53 
Polejaeva IA, Reed WA, Bunch TD, Ellis LC and White KL (1997) Prolactininduced termination of obligate diapause of mink (Mustela vison) blastocysts in vitro and subsequent establishment of embryonic stemlike cells Journal of Reproduction and Fertility 109 229-236

Renfree MB (1982) Implantation and placentation. In Reproduction in Mammals: Embryonic and Fetal Development pp 26-69 Eds CR Austin and RV Short. Cambridge University Press, Cambridge

Roberts RM, Baumbach GA, Buhi WC, Denny JB, Fitzgerald LA, Babelyn SF and Horst MN (1984) Analysis of membrane polypeptides by twodimensional polyacrylamide gel electrophoresis. In Molecular and Chemical Characterisation of Membrane Receptors pp 61-113 Eds JC Venter and LC Harrison. Alan R Liss Inc., New York

Roberts RM, Xie S and Mathialagan N (1996) Maternal recognition of pregnancy Biology of Reproduction $\mathbf{5 4}$ 294-302

Sempéré A (1977) Plasma progesterone levels in the roe deer Capreolus capreolus. Journal of Reproduction and Fertility 50 365-366

Sempéré AJ, Blanvillain C, Mauget R and Chemineau P (1993) The role of the photoperiod in the sexual cycle in female roe deer (Capreolus capreolus). In Deer in China: Biology and Management pp 364-371 Eds N Ohtaishi and HI Sheng. Elsevier, Amsterdam
Sempéré AJ, Mauget R and Mauget C (1998) Reproductive physiology of roe deer. In The European Roe Deer: The Biology of Success pp 161-188 Eds R Anderson, P Duncan and JDC Linnell. Scandinavian University Press, Oslo

Short RV and Hay MF (1966) Delayed implantation in the roe deer (Capreolus capreolus) Symposium of the Zoological Society of London 15 173-194

Xie S, Boon G, Nagel RJ, Beckers J-F and Roberts RM (1994) A novel glycoprotein of the aspartic proteinase gene family expressed in bovine placental trophectoderm Biology of Reproduction 51 1145-1153

Zoli AP, Guilbault LA, Delahaut P, Ortiz WB and Beckers J-F (1992) Radioimmunoassay of a bovine pregnancy associated glycoprotein in serum: its application for pregnancy diagnosis Biology of Reproduction 46 83-92

Received 6 September 2000.

First decision 2 November 2000.

Accepted 6 February 2001. 